\title{
Mencius, Xunzi, and the Third Stage of Confucianism
}

\author{
Tu Weiming 杜維明 \\ Professor of Philosophy, Peking University, Beijing, China \\ twm@pku.edu.cn
}

\begin{abstract}
According to Karl Jaspers's theory of the Axial age, many important cultures in the world experienced a "transcendental breakthrough" between 800 and 200 вCE; no more transformations occurred until Martin Luther's Protestant Reformation in the sixteenth century, which eventually ushered in the modern era. The implication of this theory is that only the West had a second cultural breakthrough, thus rendering moot the discussion of a third Confucian epoch. But, in reality, Confucianism had a second breakthrough during the Song-Ming period (tenth to seventeenth centuries) and spread from China to East Asia; this new form of Confucianism is called "neo-Confucianism" by Western scholars. The third Confucian epoch is a forwardlooking concept that uses the lexicon of Western science and democracy to trace Confucianism's philosophical transformation from a Chinese tradition into a part of world culture, and the integration of Mencian and Xunzian thought has to be treated in this light. Faced with Western cultural challenges, modern Confucianism has broken new ground in many ways. Mou Zongsan 牟宗三 is Mencian (as represented by Lu Xiangshan 陸象山, Wang Yangming 王陽明, and Liu Jishan 劉儎山) in spirit and Xunzian (as represented by Zhu Xi 朱喜) in practice. Li Zehou 李澤厚, by contrast, exhorts us to talk the Mencian talk but walk the Xunzian walk; this contradictory stratagem, which he thinks will lead to a brighter and healthier future, only accentuates the power of Mencius 孟子 as a philosopher of the mind. Mencius and Xunzi 荀子 are very important in a modern deconstruction of Confucianism and the integration of their thought may very well become the impetus for another transcendental breakthrough. Is integration possible? How should they be integrated? We await the results of Confucian scholars' open-minded explorations.
\end{abstract}




\section{Keywords}

The Axial Age - breakthroughs in modernity - third stage of Confucianism - creative transformation - integration of Mencius and Xunzi

\section{The Third Stage of Confucianism}

I believe that our conference today ${ }^{1}$ is both timely and necessary, as the distinguished Li Zehou 李澤厚 has recently proposed that we "raise the Mencian banner but practice the Xunzian philosophy,"2 and the indefatigable Professor Liang Tao 梁濤 has worked tirelessly to integrate Mencian and Xunzian thought. Whenever we talk about Mencius and Xunzi, the question of periodization invariably bubbles up to the surface. In December 1989, Fudan University held a symposium to discuss Confucianism and the future of Chinese society. It is remarkable that this symposium took place, and Li was invited to give a speech "Why I'm Not a Neo-Confucian," as he was thought to hew to neoConfucianism at the time. I had first communicated with Li in 1978, and we had frequent discussions for about a year after that. He subsequently wrote "Confucius Reexamined,"3 which caused quite a stir because scholars on the mainland at that time either looked askance at traditional ideas or kept their distance from Confucianism. Reexamining Confucianism and casting it in a positive light made Li a controversial figure.

As we all know, Confucianism was a controversial subject throughout the 1980s. In 1985, I was a teacher at Peking University, and my classes were attended by many graduate students who believed that theirs was a generation that could learn to critique but never identify with Confucianism, and they held rather hardened attitudes. Li caused much academic dissonance in China because he identified with Confucianism, and he was forthcoming in his answers to the questions posed to him. Why was he not a neo-Confucian? He said that his views were very different from the neo-Confucianism with which I was associated. First, he attached more importance to Xunzi and I to Mencius.

1 The conference was called “Tonghe Mengxun yu daotong chonggu 統合孟荀與道統重估 [Integrating Mencius and Xunzi]," held at the School of Confucianism, Renmin University, October 2017.

2 Li Zehou 李澤厚, “Ju mengqi, xing xunxue: Wei Lunlixue gangyao yibian 舉孟旗行荀 學—為《倫理學綱要》一讋 [Raise the Mencian Banner, Practice the Xunzian Philosophy: Defense for The Essentials of Ethics]," Tansuo yu zhengming 探索與爭鳴, no. 4 (2017).

3 Li Zehou, “Kongzi zai pingjia 孔子再評價 [Confucius Reexamined]," Zhongguo shehui kexue 中國社會科學, no. 2 (1980). 
Second, he believed that I did not pay enough attention to Confucianism in the Han [202 BCE-220]-Tang [618-907] period and did not fully understand Confucianism's important evolution during that period. Third, my emphasis appeared to be on Wang Yangming 王陽明 [1472-1529] whereas his was on Zhu Xi 朱喜 [1130-1200]. Fourth, and most importantly, he disagreed with me on the periodization of Confucianism; he believed that the third stage should more appropriately be the fourth. ${ }^{4}$

Mou Zongsan 牟宗三 [1909-1995] was the first to raise the question of the third stage of Confucianism, and scholars such as Shen Youding 沈有鼎 [1908-1989] and He Lin 賀麟 [1902-1992] studied the evolution of the stages. The gist of the matter is this: Is Confucianism capable of developing further? ${ }^{5}$ For Confucian scholars, the real question is not how the third stage developed but whether there was a second stage. The significance of Confucianism in the Song [960-1279]-Ming [1368-1644] period was not universally acknowledged at the time, and William Theodore de Bary [1919-2017] coined the term neo-Confucianism ${ }^{6}$ to denote Song-Ming Confucianism, or the second stage of Confucianism.

The larger context of all these questions is what the international academic community calls the Axial age, which is a theory advanced by Karl Theodor Jaspers [1883-1969]. Jaspers believed that several ancient cultures had important breakthroughs between 800 and 200 вСE. At first were the Greek and Hebrew cultures, followed by India and China. ${ }^{7}$ Scholars later

4 Li Zehou, "Shuo ruxue siqi 說儒學四期 [Four Epochs of Confucianism]," in Lishi bentilun: jimao wushuo zengdingben 歷史本體論.己卯五說(增訂本) [Historical Ontology: Five Essays from 1999 (Expanded and Revised Edition)] (Beijing: Shenghuo dushu xinzhi sanlian shudian, 2006).

5 Mou Zongsan 牟宗三, "Rujia xueshu de fazhan jiqi shiming 儒家學術的發展及其 使命 [Confucian Development and Mission]," in Daode de lixiang zhuyi 道德的理想 主義 [Ethical Idealism] (Taipei: Xuesheng shuju, 200o); Ren Jiantao 任劍濤, “Chongti Ruxue disanqi fazhan: Xiandaixing Ruxue jiangou de jinlu wenti 重提儒學第三期發展: 現代性 儒學建構的進路問題 [Another Look at the Third Confucian Epoch: Talking about the Forward Path of Modern Confucianism's Construction]," Jiangsu xingzheng xueyuan xuebao 江蘇行政學院學報, no. 4 (2001).

6 De Bary wrote, "First, I should explain the tendency of Song Confucianism. There was a renewed emphasis on Taoism's vitality and creativity and a new critical attitude.... Generally speaking, Neo-Confucianism, especially Taoism, was born out of the great reform movement of Northern Song Dynasty [960-1127]." William Theodore de Bary 狄百瑞, Zhongguo de ziyou chuantong 中國的自由傳統 [The Liberal Tradition in China], trans. Li Hongqi 李宏祺 (Hong Kong: Zhongwen daxue chubanshe, 1983), xii.

7 Karl Theodor Jaspers 卡爾. 雅斯貝爾斯, Lun lishi de qiyuan yu mubiao 論歷史的起源與 目標 [The Origin and Goal of History], trans. Li Xuetao 李雪濤 (Shanghai: Huadong shifan daxue chubanshe, 2018), 8-35. 
qualified the breakthroughs as transcendental. Dcedalus, a magazine from the American Academy of Arts and Sciences, published an issue titled "The Axial Age: Transcendental Breakthroughs" around that time. There is a reason for this theory. Western scholars believe that there was a breakthrough between the Axial age and the modern age, a premodern breakthrough that can be called the second period of the Axial age and is embodied by Martin Luther's [1483-1546] Reformation. It was this Protestant Reformation that made the premodern breakthrough possible, and it was the premodern breakthrough that gave birth to the modern world. The Reformation is therefore intimately linked to modernity. This is Max Weber's [1864-1920] theory, and we are all familiar with that. ${ }^{8}$ Without the Reformation, or the evolution of the second stage, the world would be merely an extension of the Axial age. The subject I discussed most with Western scholars at the time was whether China had experienced a premodern breakthrough. I believe that it did and that it was brought on by Song-Ming Confucianism. As a counterpart to the evolution and influence of Western theology, including Martin Luther, Song-Ming Confucianism's influence spread from China to other East Asian cultures. We can argue that Song-Ming Confucianism is more influential because its spread has a wider geographic scope. Western scholars believed that modernity was possible only when there was a second breakthrough after the Axial age; modernity was therefore a Western phenomenon, and other cultures could only emulate the West because they were incapable of internal breakthroughs. Of course, we can dispute this theory on many fronts. Therefore, this is the larger context of the discussions about the third stage of Confucianism.

\section{2 Confucian Periodization}

With this as the background, we think back to 1958, when Mou Zongsan and others published "A Manifesto for the Chinese Culture." The key question, in

8 Max Weber 馬克斯. 韋伯, Xinjiao lunli yu ziben zhuyi jingshen 新教倫理與資本主義 精神 [The Protestant Ethic and the Spirit of Capitalism], trans. Yan Kewen 閻克文 (Shanghai: Shanghai renmin chubanshe, 2018).

9 Mou Zongsan, Xu Fuguan 徐復觀, Zhang Junmai 張君勱, and Tang Junyi 唐君毅, “Wei Zhongguo wenhua jinggao shijie renshi xuanyan: Women dui Zhongguo xueshu yanjiu ji Zhongguo wenhua yu shijie wenhua qiantu zhi gongtong renshi 為中國文化敬告 世界人士宣言一我們對中國學術研究及中國文化與世界文化前途之共同認識 [A Manifesto for the Chinese Culture: Our Common Understanding on the Chinese Academic Research and the Prospect of Chinese Culture and World Culture]," Minzhu pinglun 民主 評論 (January 1958). 
reality, was not how many Confucian stages there were but whether China could evolve further as a culture. In other words, can Chinese culture offer anything akin to Western modernity? The question that I pondered at the time was not the order of the Confucian stages but whether Confucianism could develop further. In fact, Confucianism has many tangential possibilities for further development, but which one should we pick? I believe that Confucianism must develop further; if it appears that it cannot, we must do all that we can so that it does.

I was interested in Joseph Levenson's [1920-1969] work at the time. We all know that, in Confucian China and Its Modern Fate, Levenson proclaimed that Confucianism "belonged in the museums."10 This is his verdict on Confucianism's aspiration to modernity. This is also how Chinese intellectuals felt after the May Fourth movement, though their view was not shared by the Chinese people in general. To a large extent, the intellectuals believed that Confucianism had to die; if it still had any life left, they would have to kill it off. Confucianism had too many problems, and its only proper place was in the past. But, in reality, in the 196os Levenson began to doubt the validity of his own views: If Confucian traditions were at a dead end, how does one explain the Cultural Revolution [1966-1976] or the movement to criticize Confucius and Lin Biao 林彪 [1907-1971]? When a tradition has truly ended, no one will refer to it; if people still talk about it, it is because it has not ended.11

There was something else in the larger context that people did not know at the time. Levenson was a devout believer in Judaism. Through the study of Confucianism, he saw the fate of his own religion and, indeed, of spirituality in general. Science, democracy, technology, and industrialization have obviated the need for spiritual belief, and this includes all the major religions, such as Judaism, Christianity, Islam, and Confucianism. ${ }^{12}$ He viewed the sad fate of Confucian China not as a disinterested bystander but as a sympathetic observer.

Levenson once told a story of modern Jewish culture. When the spiritual leader of the first generation had a problem, he went up to the mountain and performed a ceremony; he knew the significance and the details of the

10 Joseph R. Levenson, Confucian China and Its Modern Fate (Berkeley: University of California Press, 1965).

11 Joseph R. Levenson, “Geming yu shijie zhuyi: Zhongxi wutai zhijian 革命與世界主義: 中西舞臺之間 [Revolution and Cosmopolitanism: The Western Stage and the Chinese Stages]," Zhongguo xiandai wenxue yanjiu congkan 中國現代文學研究叢刊, trans. He Jixian 何吉賢, no. 4 (2020).

12 Levenson, Confucian China and Its Modern Fate. This point is made repeatedly throughout the book. 
ceremony, and afterward the problem was solved. When the spiritual leader of the second generation had a problem, he went up to the mountain and performed a ceremony; he no longer knew the significance of the ceremony but was able to solve the problem afterward. When the spiritual leader of the third generation had a problem, he went up to the mountain and performed a ceremony; he was not sure what to do in the ceremony but knew the location he needed to go on the mountain. Today's Jewish scholars sit in lecture halls and conference rooms to discuss spiritual events of the past; they are aware that some ceremonies took place but do not know their location, details, or significance. ${ }^{13}$ This is our fate! Levenson looked at humanity and spirituality from this perspective, and it is a wake-up call, for Confucianism faces the same set of problems.

A tradition needs to transform its philosophical core to survive, so this is a philosophical question. But, at its root, it is also a spiritual question. This is not to say that Confucianism lacks political, practical, and emotional impact or that it is bereft of filial piety and loyalty. Confucianism has all these things, and the only thing that is missing is true philosophical creativity. Can we recreate Confucianism so that it has room to develop? At the core of all the discussions about the third stage of Confucianism is the question: "Is the third stage even possible?" This is the first point I want to make.

My second point has to do with periodization, and I have talked at length with Li on this subject. Periodization is important for historians. How do we create periodization for historical Confucianism? This is a different question from the existence of the third stage. Asking whether a third stage exists is tantamount to asking how Confucianism can develop in the twenty-first century. As for specific periodization, you can call it the third, the fourth, or the fifth stage; it does not really matter. The real question is: can Confucianism develop further? Apart from the question of the third stage, I share many of Li's views, but I also believe that Guo Qiyong's 郭齊勇 views are better. ${ }^{14}$ Confucianism in the Han, Sui [581-619], and Tang dynasties are no doubt important, but Qing [1644-1911] Confucianism is also key. If you pay scant attention to Qing Confucianism, or if you are lax in studying the social problems before and after the Opium War [1840-1842], how can you hope to have any understanding of the third stage? Historians of philosophy rarely argue over differences in periodization. I have said that it is more in keeping with historical facts that

13 Levenson, Confucian China and Its Modern Fate, 383-84.

14 Guo Qiyong believes that Confucianism has passed through four historical stages. See Guo Qiyong 郭齊勇, Zhongguo ruxue zhi jingshen 中國儒學之精神 [Essence of Confucianism] (Shanghai: Fudan daxue chubanshe, 2009). 
we divide Confucianism into ten stages. What I meant by this was that Yuan [1271-1368] Confucianism is certainly distinct from Song Confucianism, and when we consider Liu Yin 劉因 [1249-1293] and Wu Cheng 吳澄 [1249-1333] of the Yuan dynasty and the Confucian development after the Ming dynasty, many topics are worthy of study.

There is no conflict between Li and me on the second point. Can one really claim to understand Confucianism without a deeper knowledge of Xunzi? Some Western scholars like to view Confucius, Mencius, and Xunzi as the counterparts to Socrates [469-399 ВСE], Plato [427-347 BCE], and Aristotle [384-322 вCE]. This is a somewhat exaggerated view to be sure, but Xunzi is similar to Aristotle in many ways, and this only makes Han Confucianism, or the work of Dong Zhongshu 董仲舒 [179-104 BCE] in particular, that much more important.

Another point I want to make is that Mou thinks highly of Lu Xiangshan 陸象山 [1139-1193] and Wang Yangming but seems to lack respect for Zhu Xi, whose work he deems apocryphal. But I find that the driving force behind his study of Song-Ming Confucianism, including the writing of his book Mind and Nature [Xinti yu xingti 心體與性體], ${ }^{15}$ is the desire to understand $\mathrm{Zhu} \mathrm{Xi}$, so in this respect Zhu Xi is the most important subject for him. I once asked him, "Do you think the evolution of Lu's and Wang's thought is not as important?" He responded by writing From Lu Xiangshan to Liu Jishan, ${ }^{16}$ but it was a quick sketch of a book; he wrote it in a hurry. What he really wanted to concentrate his energy on was to relate Zhu's philosophy to the evolution of Song Confucianism. Sometimes, a genealogy of philosophical thought and a scholar's interest in an academic subject are two different things. A philosophical genealogy is not the same as an objective study. There are two ways for a scholar to choose a philosophical genealogy, through what is described in academic history or a classification of teachings, which, in the end, can be either right or wrong. I believe that Zhu Xi sometimes showed an error of judgment in assessing Mencius, but Zhu did not really take up the mantel of Mencius, and Lu Xiangshan and Wang Yangming did. It is clear that Mou wanted to create a classification of Zhu's teachings, but he also wanted to tackle the question of reason - whether reason is being or doing, active or inactive. Many other fine points are also worthy of academic discussion.

15 Mou Zongsan, Xinti yu xingti 心體與性體 [Mind and Nature] (Shanghai: Shanghai guji chubanshe, 1999).

16 Mou Zongsan, Cong Lu Xiangshan dao Liu Jishan 從陸象山到劉藏山 [From Lu Xiangshan to Liu Jishan] (Taipei: Taiwan xuesheng shuju, 1979). 
Mou and I differ on another point: I do not believe that Chinese academic traditions should be the only standard for Confucianism. The work of Korean and Japanese scholars after the Song-Ming period is important, and now it seems that we must include the work of Vietnamese and other scholars as well. Yi Hwang 李滉 [1501-1570] was the most important Confucian scholar from Korea. This acolyte of Zhu Xi put forth the concept of "four virtues and seven emotions" [siduan qiqing shuo 四端七情說] as his reply to the questions raised by Wang Yangming, and we have not paid enough attention to this argument. Yi broached the question of reason and $q i$ 氣 in this work. It is his belief that the four virtues are activated by reason and merged subsequently with $q i$ whereas the seven emotions are activated by $q i$ and subsequently harnessed by reason. ${ }^{17}$ Reason and $q i$ are intimately related yet fundamentally different, and we should never mix them together. I have no trouble accepting this approach. Philosophically speaking, the greatest difference between Li and me is that I cannot accept emotion-as-being, especially the tendency to treat emotion at the level of experience or everyday logic. This goes against the spiritual grain of Mencius and Zhu Xi, not to mention the tradition of Lu Xiangshan, Wang Yangming, and Liu Zongzhou 劉宗周 [1578-1645]. We can argue a lot of points here. Why raise the Mencian banner and practice the Xunzian philosophy? ${ }^{18}$ Li gave his reasons, but reading them made me draw the opposite conclusion. There is no need to raise the Mencian banner because Xunzian thought is already mainstream. He said that Xunzian thought permeated two thousand years of Chinese history; he even made Zhu Xi a part of Xunzi's thought. Zhu would probably turn over in his grave if he could hear this. Li has spent a lot of time studying Mencius, only to conclude that Mencian thought is part of Xunzian thought. Of course, there is no doubt that the questions Li raised are seminal and worthy of discussion because they involve Confucianism's development in the modern age.

Another question is the development of the Axial cultures. Confucianism spread from Qufu 曲阜 to the Central Plain and became a major part of Chinese culture; this is Confucianism's first stage. But why is there a second stage? This is the biggest point of contention among Western scholars. If this second stage exists, it means that Confucianism has become part of East Asian culture and

\footnotetext{
17 Yi Hwang 李滉 and Ki Tae-sung 奇大升, Yangseonsaeng sachil igi wangbokseo 兩先生 四七理氣往復書 [Correspondence Regarding Reason and Qi] (Seoul: Hakseonjae, 2017), 11, 44-45; Yi Hwang, Toegyejip 退溪集 [Tuixi Collection] (Seoul: Hanguk gojeon beonyeok hagwon, 1989), 423 .

18 Li Zehou, “Ju mengqi, xing xunxue." Professor Yang Zebo 楊澤波 offered a critique of this in “Rengshi yipian: Lun Li Zehou de xin pangchushuo 仍是一偏: 論李澤厚的新旁出說 [Another Bias: Li Zehou's New Theory]," Tansuo yu zhengming, no. 7 (2017).
} 
not just part of Chinese culture; ${ }^{19}$ this point has been made by Japanese scholars, such as Kenji Shimada 島田虔次 [1917-200o]. Can Confucianism develop to become a part of world culture? This is not just a philosophical question or a topic for Chinese academia. I once had a conversation with Yu Yingshi 余英時 and longtime Singaporean leader Lee Kuan Yew 李光耀 [1923-2015]; that was the only time I conversed with them. Lee asked a direct question: "Can we talk about Confucianism in English?" Yu's answer was equally direct: "No, because you lose the original flavor." What Yu meant was that it would be absurd to talk about Confucianism if one did not speak Chinese or did not understand ancient Chinese texts. Korean Confucianism was able to develop because Korean scholars all knew ancient Chinese. Yi Hwang was so adept at the Chinese language that, after a Qing editor of Siku quanshu 四庫全書 had read Yi's writings, he noted in his diary, "Orthodox Confucian writer of unknown dynastic origin." Was Yi from the Song or Yuan dynasty? It never occurred to the Qing editor that Yi was Korean. It is the same with Japanese scholars. Kojiro Yoshikawa 吉川幸次郎 [1904-1980] once said that Confucian scholars in Japan were so proficient in the Chinese language that it would take Western scholars one or two hundred years to equal them. We can therefore see the reason for Yu's statement. But another way of looking at this is that if Confucianism cannot express its core values in any language other than Chinese and must rely on simplistic translations, it will never become a major part of world culture. I will give an example for the sake of comparison. We all know that Christianity, Islam, and Buddhism are the three major religions in the world, and each has its own core language - Hebrew for Christianity, Arabic for Islam, and Sanskrit or Pali for Buddhism. If you want to discuss Islam, it is best that you use Arabic. You cannot be a great Islamic thinker if you do not speak Arabic because most Muslim countries, including large and influential ones such as Indonesia, use Arabic. There is a huge difference between Arabic Islam and non-Arabic Islam. Some scholars believe that only three languages can express the Islamic culture in the premodern era: Arabic, Urdu, and Turkish. I did a little research on scholars such as Wang Daiyu 王岱舆 [1584-1670] and Liu Zhi 劉智 [1669-1764] and found their contribution as great as that of Huang Zongxi 黄宗羲 [16101695]. People marveled at Liu Zhi, who opened up a new world for Arab culture in the eighteenth century using a language other than Arabic or Turkish. Liu's

19 According to Tang Yijie 湯一介 [1927-2014], at the end of the 1970s, Kenji Shimada criticized the repudiation of Confucius and Lin Biao during the Cultural Revolution by saying "Confucianism belongs to East Asian culture, not just Chinese culture." See Li Huaiyu 李懷宇, “Tang Yijie: Zuo Ruzang zhanzhan jingjing 湯一介: 做《儒藏》戰戰兢兢 [Tang Yijie: The Confucian Project Hangs by a Thread]," Shiji renwu世紀人物, no. 11 (2014). 
Heaven and Nature [Tianfang xingli 天方性理 ${ }^{20}$ was translated into Arabic, and he subsequently made his mark in the Western world; he was truly an original thinker. As for the other religions, speaking only Chinese, or English or French for that matter, does not prevent me from becoming a devout Christian today; and if I do not understand Sanskrit or Pali and know only Chinese or Tibetan, nothing stands in the way of my becoming a zen master or a respected practitioner of Buddhism. Now we see the challenges facing Confucianism in the modern world. We have pondered the question posed by Lee Kuan Yew and talked about the integration of Mencian and Xunzian thought. No matter how Confucianism develops on the mainland, or how the various philosophical tenets are unified, we cannot avoid the questions I just posed, because behind all these questions is the thorny problem of modernizing ancient Confucian traditions. Against this backdrop, we need to specify what work needs to be done to integrate Mencian and Xunzian thought.

There is one last matter I would like to discuss. Scholars from Xiong Shili 熊十力 [1885-1968] and Liang Shuming 梁漱溟 [1893-1988], including Zhang Junmai 張君勱 [1887-1969] and He Lin who stopped talking about Confucianism in his old age, to Tang Junyi 唐君毅 [1909-1978], Mou Zongsan, Xu Fuguan 徐複觀 [1903-1982], and Qian Mu 錢穆 [1895-199o] all agreed that we must ponder the question of Confucian development in the modern era. To quote Emmanuel Levinas [1906-1995], ethics is China's first philosophy. This includes both theory and praxis, both of which are intimately related to metaphysics, cosmology, and ontology. Will they withstand the turgid philosophical tides of the West? If we set aside the question of how we can tweak the inner saints and outer kings, we should first ask whether we can bring science and democracy to China only through the "self-denial of conscience." ${ }^{11}$ Questions such as these now generate many lively discussions in China. What we should also ask is: where should the starting point of the third Confucian stage be? Should it start with Xiong Shili, Kang Youwei 康有為 [1858-1927], or even earlier? All these points are up

20 Liu Zhi 劉智, Tianfang xingli 天方性理 [Heaven and Nature] (Shanghai: Shanghai guji chubanshe, 1996).

21 The idea of "self-denial of conscience" comes from Mou Zongsan. See Xie Yuansun 謝遠简, “Mou Zongsan ‘liangzhi kanxian’ shuo de yihan ji yu Kang De, Heige’er de xiangguanxing 牟宗三“良知坎陷”說的意涵及與康得、黑格爾的相關性 [Mou Zongsan’s Theory of Self-Denying of Conscience and Its Relationship to Kant and Hegel]," Zhexue yanjiu 哲學研究, no. 3 (2020). 
for discussion. My view is that if you want to talk about modern Confucianism and you do not start with Kang Youwei, Liang Shuming, or even Wei Yuan 魏源 [1794-1857], you will have a hard time explaining things historically. Faced with the challenges posed by Western culture, Confucianism could develop in many different ways, but its core has to be a philosophy of the mind and nature. So, where do we go from here? If we take the Xunzian road, what does the future look like? And if we take the Mencian path, what can we expect ahead? All the scholars I just mentioned think that we should let Mencius lead the way. Li thinks that Xunzi is more conducive to future Confucian development but insists on marching under the Mencian banner. But why? Professor Liang Tao wants to rebuild Confucianism by integrating Mencius and Xunzi. But how?

\section{Translated by Eric Chiang}

\section{Works Cited}

De Bary, William Theodore 狄百瑞. Zhongguo de ziyou chuantong 中國的自由 傳統 [The Liberal Tradition in China]. Translated by Li Hongqi 李宏祺. Hong Kong: Zhongwen daxue chubanshe, 1983.

Guo Qiyong 郭齊勇. Zhongguo ruxue zhi jingshen 中國儒學之精神 [Essence of Confucianism]. Shanghai: Fudan daxue chubanshe, 2009.

Jaspers, Karl Theodor 卡爾 雅斯貝爾斯. Lun lishi de qiyuan yu mubiao 論歷史的起源 與目標 [The Origin and Goal of History]. Translated by Li Xuetao 李雪濤. Shanghai: Huadong shifan daxue chubanshe, 2018.

Levenson, Joseph R. Confucian China and Its Modern Fate. Berkeley: University of California Press, 1965.

Levenson, Joseph R. “Geming yu shijie zhuyi: Zhongxi wutai zhijian 革命與世界主 義: 中西舞臺之間 [Revolution and Cosmopolitanism: The Western Stage and the Chinese Stages]." Translated by He Jixian 何吉賢. Zhongguo xiandai wenxue yanjiu congkan 中國現代文學研究叢刊, no. 4 (2020): 113-48.

Li Huaiyu 李懷宇. “Tang Yijie: Zuo Ruzang zhanzhan jingjing 湯一介: 做《儒藏》戰戰 兢㜔 [Tang Yijie: The Confucian Project Hangs by a Thread]." Shiji renwu 世紀人物, no. 11 (2014): 90-93.

Li Zehou 李澤厚. “Kongzi zai pingjia 孔子再評價 [Confucius Reexamined].” Zhongguo shehui kexue 中國社會科學, no. 2 (1980): 77-96.

Li Zehou 李澤厚. “Shuo ruxue siqi 說儒學四期 [Four Epochs of Confucianism].” In Lishi bentilun: jimao wushuo zengdingben 歷史本體論・己印五說(增訂本) [Historical Ontology: Five Essays from 1999 (Expanded and Revised Edition)], 130-55. Beijing: Shenghuo dushu xinzhi sanlian shudian, 2006. 
Li Zehou 李澤厚. “Ju mengqi, xing xunxue: Wei Lunlixue gangyao yibian 舉孟旗 行荷學一為《倫理學綱要》一辯 [Raise the Mencian Banner, Practice the Xunzian Philosophy: Defense for The Essentials of Ethics]." Tansuo yu zhengming 探索與 爭鳴, no. 4 (2017): 58-62.

Liu Zhi 劉智. Tianfang xingli 天方性理 [Heaven and Nature]. Shanghai: Shanghai guji chubanshe, 1996.

Mou Zongsan 牟宗三. Cong Lu Xiangshan dao Liu Jishan 從陸象山到劉瀻山 [From Lu Xiangshan to Liu Jishan]. Taipei: Taiwan xuesheng shuju, 1979.

Mou Zongsan 牟宗三. Xinti yu xingti 心體與性體 [Mind and Nature]. Shanghai: Shanghai guji chubanshe, 1999 .

Mou Zongsan 牟宗三. "Rujia xueshu de fazhan jiqi shiming 儒家學術的發展及其使命 [Confucian Development and Mission].” In Daode de lixiang zhuyi 道德的理想主義 [Ethical Idealism], 1-12. Taipei: Xuesheng shuju, 2000.

Mou Zongsan 牟宗三, Xu Fuguan 徐復觀, Zhang Junmai 張君勱, and Tang Junyi 唐君毅. “Wei Zhongguo wenhua jinggao shijie renshi xuanyan: Women dui Zhongguo xueshu yanjiu ji Zhongguo wenhua yu shijie wenhua qiantu zhi gongtong renshi 為中國文化敬告世界人士宣言一我們對中國學術研究及中國文化與世界文 化前途之共同認識 [A Manifesto for the Chinese Culture: Our Common Understanding on the Chinese Academic Research and the Prospect of Chinese Culture and World Culture]." Minzhu pinglun 民主評論 (January 1958).

Ren Jiantao 任劍濤. “Chongti Ruxue disanqi fazhan: Xiandaixing Ruxue jiangou de jinlu wenti 重提儒學第三期發展: 現代性儒學建構的進路問題 [Another Look at the Third Confucian Epoch: Talking about the Forward Path of Modern Confucianism's Construction]." Jiangsu xingzheng xueyuan xuebao 江蘇行政學院學報, no. 4 (2001): 33-39.

Weber, Max 馬克斯 韋伯. Xinjiao lunli yu ziben zhuyi jingshen 新教倫理與資本主義 精神 [The Protestant Ethic and the Spirit of Capitalism]. Translated by Yan Kewen 閻克文. Shanghai: Shanghai renmin chubanshe, 2018.

Xie Yuansun 謝遠简. “Mou Zongsan 'liangzhi kanxian' shuo de yihan ji yu Kang De, Heige'er de xiangguanxing 牟宗三 “良知坎陷” 說的意涵及與康得、黑格爾的相 關性 [Mou Zongsan's Theory of Self-Denying of Conscience and Its Relationship to Kant and Hegel]." Zhexue yanjiu 哲學研究, no. 3 (2020): 80-89.

Yang Zebo 楊澤波. “Rengshi yipian: Lun Li Zehou de xin pangchushuo 仍是一偏: 論 李澤厚的新旁出說 [Another Bias: Li Zehou's New Theory].” Tansuo yu zhengming, no. 7 (2017): 6o-66.

Yi Hwang 李滉. Toegyejip 退溪集 [Tuixi Collection]. Seoul: Hanguk gojeon beonyeok hagwon, 1989 .

Yi Hwang 李滉 and Ki Tae-sung 奇大升. Yangseonsaeng Sachil Igi Wangbokseo 兩先 生四七理氣往復書 [Correspondence Regarding Reason and Qi]. Seoul: Hakseonjae, 2017. 